\title{
On the distinctive call of a threatened phenotype of Allobates femoralis (Anura: Aromobatidae) and its recognition by allopatric conspecific males
}

\author{
Emerson Pontes-da-Silva ${ }^{1,3}$, Albertina P. Lima' \& Pedro I. Simões ${ }^{1,2}$
}

\footnotetext{
1. Coordenação de Biodiversidade (CBIO), Instituto Nacional de Pesquisas da Amazônia (INPA), Av. André Araújo, 2936, 6901 1-970, Manaus, AM, Brazil. (albertina.lima59@gmail.com)

2. Laboratório de Sistemática de Vertebrados, Faculdade de Biociências, Pontifícia Universidade Católica do Rio Grande do Sul (PUCRS), Av. Ipiranga, 6681, 90619-900,

Porto Alegre, RS, Brazil. (pedro.simoes@pucrs.br)

3. Programa de Pós-Graduação em Ecologia, Instituto Nacional de Pesquisas da Amazônia (INPA), Av. André Araújo, 2936, 6901 1-970, Manaus, AM, Brazil (emersonpontesbio@gmail.com)
}

Received 17 May 2016

Accepted 12 May 2017

DOI 10.1590/1678-4766e2017028

\begin{abstract}
The brilliant-thighed frog [Allobates femoralis (Boulenger, 1884)] is distributed across the Amazon basin and aggregates several allopatric evolutionary lineages, some of which present variation in their advertisement calls. In 2009, an unregistered call phenotype was discovered in the region of Altamira and Vitória do Xingu, State of Pará, Brazil, where males emit advertisement calls formed by six notes, differing from the typical four-note calls described for other $A$. femoralis populations. In this study, we describe in detail these untypical calls. Additionally, we test whether the aggressive responses of males of a 4-note reference population (Reserva Ducke - RFAD, in Manaus, States of Amazonas) is differential towards the 6-note calls of males recorded in Altamira (Pará State), and towards 4-note calls recorded in one location at the Tapajós-Xingu interfluve (Belterra, Pará State), and in RFAD. Playback experiments were conducted between 2011-2012, and used standardized stimuli produced from natural call recordings. A total of 30 independent experiments were conducted, 10 for each stimuli class. We measured the phonotaxis of focal males in relation to the loudspeaker, considering the time to orientation and the time to approach the loudspeaker. We found that not all $\mathrm{A}$. femoralis males at RFAD promptly recognize calls from males recorded in Altamira. However, when considering only males who approached the loudspeaker, differences in aggressive reactions were not seen between stimuli classes. Our findings show that the ability to recognize calls from Altamira as belonging to co-specific males is not universal among males at RFAD. The new $A$. femoralis phenotype occurs in areas potentially impacted by the Belo Monte hydroelectric complex and complementary studies indicate that no gene flow exists between this group and A. femoralis from adjacent regions. Hence, developments in Altamira may put this incipient speciation process at risk.
\end{abstract}

KEYWORDS. Advertisement calls, Dendrobatoidea, playbacks, Belo Monte dam, territorial behavior.

Acoustic signals are fundamental for long-range communication in anurans, and especially important in intraspecific interactions (GERHARDT \& HUBER, 2002; WeLLS, 2007). Advertisement calls are usually the most frequent and conspicuous signals emitted by anurans and often have multiple roles, acting both as mating signals and as cues for territory ownership by a particular male individual (GERHARDT, 1992; PröHL, 2005).In the context of territoriality and intraspecific aggressive behavior, the accurate detection of conspecific calls is essential in verifying the presence and position of intruders within the defended area within one's home range, which might contain key reproductive and survival resources (DonNelly, 1989a,b; Poelman \& Dike, 2008). Mistaking heterospecific for conspecific acoustic signals might, for example, produce an unnecessary aggressive physical response. Such interactions can be energetically costly or expose the territory holder to a greater risk of being seized by predators.
However, intraspecific differentiation in advertisement calls is common among anurans, and might involve changes in average and range values of continuous acoustic traits (e.g. duration, bandwidth, peak frequency) of elements that constitute the acoustic signal, or more obvious shifts in composition of elements of call repertoire (BEE et al., 2001; RYAN \& RAND, 2003; Boul et al., 2007; GuERRA \& RoN, 2008; RodRíGUEZ et al., 2010). Although intraspecific variation of discrete elements occurs to some extent among acoustic signals of sympatric males of Neotropical anurans (e.g., GuerRa \& Ron, 2008; Simões \& Lima, 2011), fixed differences have also been reported among allopatric groups of individuals, and these differences have been generally attributed to evolutionary effects of isolation by distance or vicariance, potentially reinforced by sexual selection (BouL et al., 2007; GUERRA \& Ron, 2008; AMÉZQUITA et al., 2009).

The Allobates femoralis complex (Anura: Aromobatidae) comprehends a large number of closely 
related evolutionary lineages of diurnal leaf-litter frogs, widely distributed in terra-firme forests of the Amazon basin, which are currently classified as a single taxon (Grant et al., 2006; Santos et al., 2009; Simões et al., 2010). Throughout their distribution, some of these lineages present conspicuous variations in their advertisement calls, which play a key role in territory defence by males, who use sound cues to readily locate and attack conspecific intruders (HöDL, 1987; AMÉZQUITA et al., 2006; URSPRUNG et al., 2009). Variation in the number of notes that constitute each call has been reported for the species. However, calls tend not to vary in relation to note number within the same lineage or population (AмÉzQuita et al., 2006, 2009).

In 2009, a distinct call phenotype was discovered in the region of Altamira, on the left bank of the Xingu River, a clear-water southern tributary of the Amazon. In this location, A. femoralis males emit calls formed by six notes, a pattern distinct from that of the typical, and geographically prevailing advertisement calls, formed by four notes (AMÉZQUiTA et al., 2009; SimõEs et al., 2014). The evolutionary implications of call variation in A. femoralis from Altamira are vastly unknown, but no sharing of mitochondrial DNA haplotypes is detected between this group and other $A$. femoralis distributed in locations adjacent to the geographic boundaries of the Altamira region (SIMÕES et al., 2014). Also, areas occupied by this novel acoustic phenotype are currently at risk, being potentially affected by large-scale developmental projects, which include the construction of the Belo Monte hydroelectric power-plant, and its associated dams and reservoirs (FEARNSIDE, 2006). Evidence relating geographically restricted call differentiation to the loss of intraspecific recognition would imply that deforestation, flooding or induced drought resulting from damming the Xingu River could put an incipient speciation process in jeopardy.

In this study, we characterize the calls of Allobates femoralis recorded in the vicinities of the cities of Altamira and Vitória do Xingu, in the State of Pará, Brazil. Additionally, we investigate possible effects of call differentiation on intraspecific male-male recognition considering a territorial behavior context. Using playback experiments, we test whether $A$. femoralis males from Reserva Florestal Adolpho Ducke (RFAD), a $100 \mathrm{~km}^{2}$ forest fragment in Manaus, central Amazonia, present different aggressive territorial responses towards calls formed by six notes recorded in Altamira, when compared to calls of sympatric males, and calls recorded in a third location, approximately $300 \mathrm{~km}$ west of Altamira, where males emit calls formed by four-notes, resembling those emitted by A. femoralis at RFAD.

\section{MATERIALS AND METHODS}

Characterization of advertisement calls was based on 11 call recordings of 11 individuals conducted in four sampling sites near the cities of Altamira and Vitória do Xingu (Fig. 1a, b) between March 2009 and February 2010. Calls were recorded with a Sony WM D6C cassette tape recorder or a Marantz PMD660 digital recorder, and Sennheiser ME66 directional microphones positioned about $1.0 \mathrm{~m}$ from the focal male. When necessary, calls were digitized from tapes at $44.1 \mathrm{kHz}$ and 16 bit resolution using Raven 1.3 software (CHARIF et al., 2004). For digital recordings, we applied a sampling rate of $44.1 \mathrm{kHz}$. From each individual recording, we selected three calls from the section that contained the least background noise. The first and the last two calls of each calling bout were never selected, in order to avoid accounting variation introduced by warm-up calls and fatigue. From each call, we measured a set of 34 acoustic variables relating to temporal and spectral parameters of the call (Tab. I), individual notes and silent intervals. Spectral analyses were conducted with a frequency resolution of $82 \mathrm{~Hz}$ and 2048 points. All measurements were conducted in Raven 1.3. Final values are presented as the average across the individual mean values for each call parameter.

We conducted field playback experiments at the Reserva Florestal Adolpho Ducke (RFAD), a $100 \mathrm{~km}^{2}$ natural reserve of well-preserved primary rainforest north of the city of Manaus, central Amazonia, Brazil (02 $55^{\prime}$ $\left.03^{\circ} 01^{\prime} \mathrm{S}, 59^{\circ} 53^{\prime}-59^{\circ} 59^{\prime} \mathrm{W}\right)$. Experiments aimed to test whether $A$. femoralis males from RFAD presented distinct aggressive responses towards calls formed by six notes recorded in the Altamira region, and calls formed by four notes, recorded in Belterra $(\sim 300 \mathrm{~km}$ west of Altamira, $03^{\circ} 09^{\prime} 27^{\prime}$ 'S, $54^{\circ} 51^{\prime} 34^{\prime \prime} \mathrm{W}$ ) and Manaus (sympatric males recorded at RFAD) (. 1a).

Acoustic stimuli used in the experiments were prepared by editing original recordings of natural $A$. femoralis calls obtained in the three locations. Stimuli were standardized in relation to number of calls per call bout ( 20 calls/bout), duration of silent intervals between call bouts ( 5 seconds) and call amplitude $(20 \mathrm{~dB})$. Call editing was performed in Raven 1.3. A total of 10 independent stimuli (i.e., derived from natural calls of 10 distinct males) were prepared for each treatment and stored in.WAV digital format. A brief characterization of the acoustic stimuli is available in Tab. II and Fig. 2.

Playback experiments at RFAD were carried out from December 2011 to April 2012, during the local rainy season, overlapping with the expected peak of reproductive activity for A. femoralis in the reserve (Lima et al., 2006). Playback procedures followed ERDTMANN et al. (2011). Each experiment began with the visual location of a calling focal male, and consisted in the broadcast of an acoustic stimulus from a fixed distance of $1.5 \mathrm{~m}$ from the calling male. Stimuli were broadcast using a digital portable sound player (G-flash wma-mp3 player, Maxfield, Germany) and portable loudspeakers (SRS-M30, Sony, Thailand). Volume controls of loudspeakers and sound players were fixed to represent a stimulus intensity of $75 \mathrm{~dB}$ at $1.5 \mathrm{~m}$ from the loudspeakers. Experiments were conducted by a sound operator and one observer. Broadcast started as soon as the focal male had resumed calling after placement of the loudspeakers by the sound operator. The experiment ended when males 


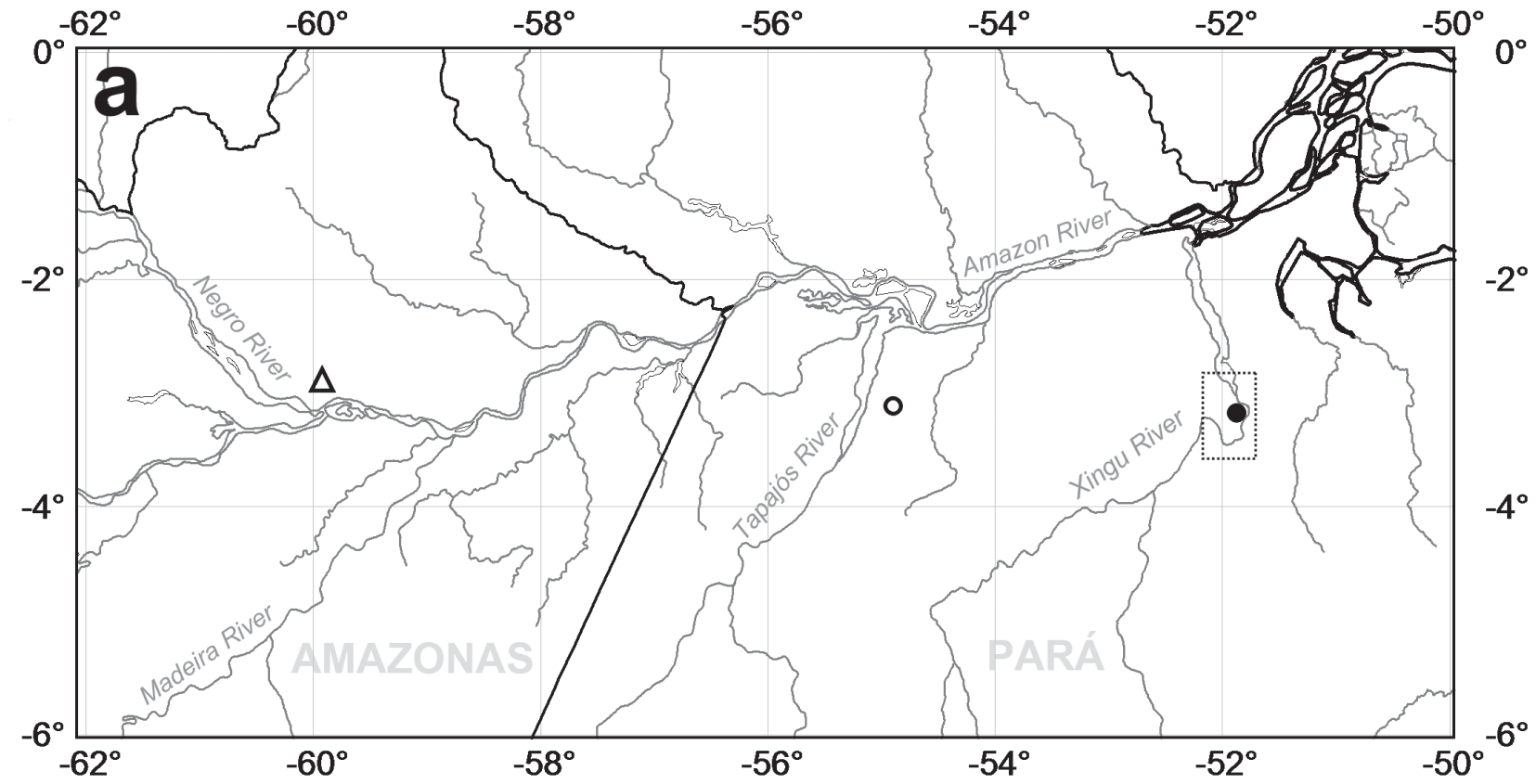

Scale: $1: 7945889$ at Latitude $0^{\circ}$
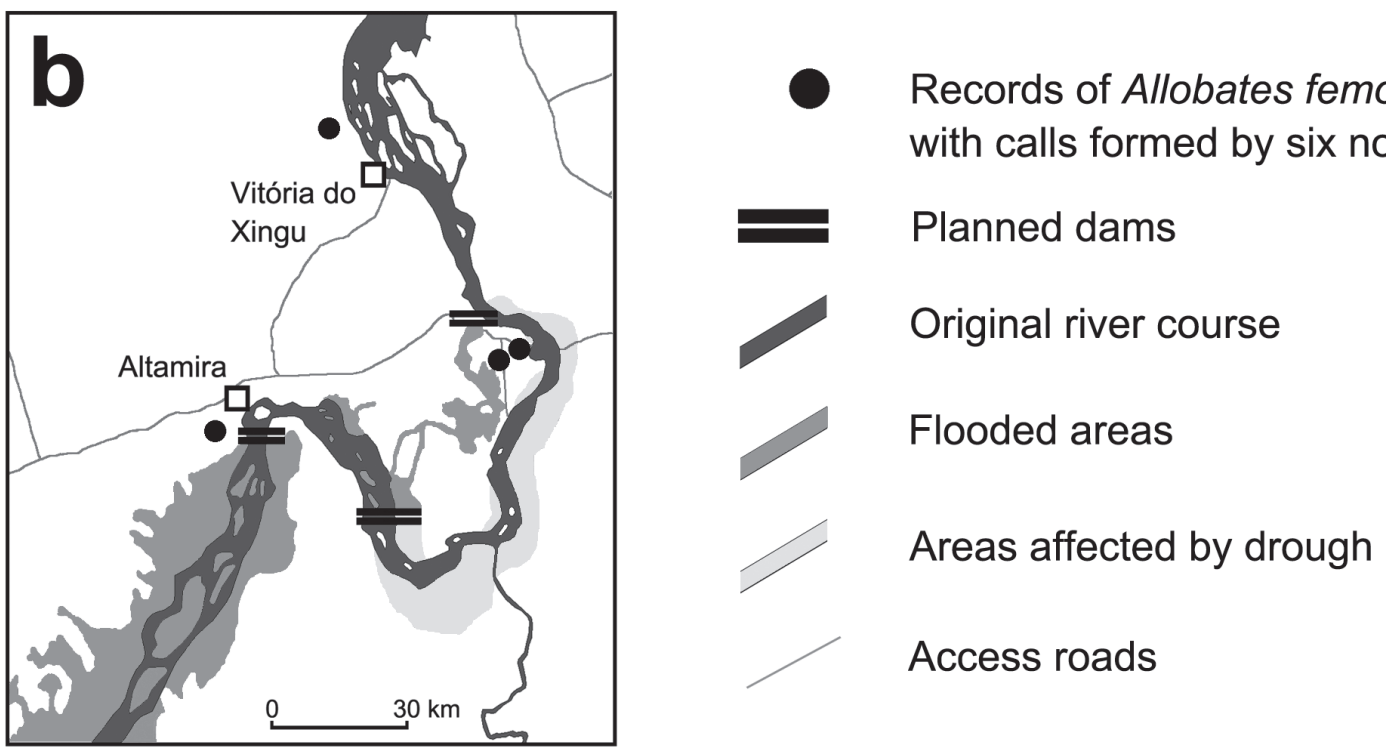

Fig. 1. (A) Location of the study site and sources of Allobates femoralis (Boulenger, 1884) acoustic stimuli in the Central Brazilian Amazon. Open triangle: Reserva Ducke (RFAD), north of Manaus, State of Amazonas, where behavioral experiments were conducted. At RFAD A. femoralis males emit advertisement calls formed by four notes. Open dot: Belterra, State of Pará, where A. femoralis males also emit calls formed by four notes. Solid dot: Altamira, State of Pará, where A. femoralis males emit calls formed by six notes. (B) Distribution of the six-note advertisement call phenotype of $A$. femoralis in the Altamira region (gray dots) and depiction of hypothesized effects of Belo Monte power plant along the area delimited by a black dashed line in (A). The estimation of impacted areas was adapted from SEví FILHO (2005) and does not depict effects predicted from forest clearing and other human activities around the urban perimeters of Altamira and Vitória do Xingu.

had moved into a $30 \mathrm{~cm}$ radius from the loudspeakers or after seven minutes of broadcast without any phonotactic behavior. During the experiment, the observer registered the time elapsed from broadcast start to the focal male's first orientation towards the stimulus (latency to orientation), and the time to reaching the $<30 \mathrm{~cm}$ radius around the loudspeakers (latency to approach). Focal males that did not respond phonotactically to an allopatric stimulus from
Altamira or Belterra were immediately subjected to control experiments with a stimulus from RFAD.

To avoid pseudo-replication, each focal male was tested only once and for a single acoustic stimulus. Differences in the aggressive behavior of males towards the three classes of acoustic stimuli were evaluated with the non-parametric Kruskal-Wallis test, performed in Systat 8.0 (WILKINSON, 1990). 
Tab. I. Temporal and spectral parameters of advertisement calls measured from 11 Allobates femoralis (Boulenger, 1884) males recorded near Altamira, State of Pará, Brazil, between March 2009 and February 2010. Three calls were sampled from each male. Average values between calls of each male were used to calculate overall means, standard deviations, and ranges of each parameter. Relative position of notes and silent intervals are depicted in Fig. 3b.

\begin{tabular}{|c|c|}
\hline Measurement & Mean \pm 1 SD $(\min -\max )$ \\
\hline Silent interval between calls (s) & $0.69 \pm 0.18(0.52-1.16)$ \\
\hline Call duration (s) & $0.64 \pm 0.03(0.58-0.69)$ \\
\hline Peak frequency of call (Hz) & $3511.53 \pm 149.99(3316.10-3836.50)$ \\
\hline Lower frequency of call (Hz) & $3093.20 \pm 91.71(2884.60-3204.63)$ \\
\hline Upper frequency of call $(\mathrm{Hz})$ & $4117.57 \pm 103.09(4010.30-4325.63)$ \\
\hline Duration of the 1 st note (s) & $0.04 \pm 0.01(0.02-0.05)$ \\
\hline Duration of the 2 nd note (s) & $0.06 \pm 0.01(0.04-0.07)$ \\
\hline Duration of the 3 rd note (s) & $0.04 \pm 0.01(0.03-0.05)$ \\
\hline Duration of the 4 th note (s) & $0.06 \pm 0.01(0.05-0.08)$ \\
\hline Duration of the 5 th note (s) & $0.04 \pm 0.01(0.03-0.05)$ \\
\hline Duration of the 6 th note $(\mathrm{s})$ & $0.06 \pm 0.01(0.05-0.08)$ \\
\hline Silent interval I (s) & $0.03 \pm 0.01(0.02-0.04)$ \\
\hline Silent interval II (s) & $0.10 \pm 0.01(0.09-0.12)$ \\
\hline Silent interval III (s) & $0.03 \pm 0.01(0.02-0.038)$ \\
\hline Silent interval IV (s) & $0.12 \pm 0.01(0.10-0.14)$ \\
\hline Silent interval V (s) & $0.029 \pm 0.01(0.019-0.038)$ \\
\hline Peak frequency of 1 st note $(\mathrm{Hz})$ & $3423.12 \pm 97.75(3291.00-3585.26)$ \\
\hline Lower frequency of 1 st note $(\mathrm{Hz})$ & $3090.63 \pm 89.31(2885.93-3208.30)$ \\
\hline Upper frequency of 1 st note $(\mathrm{Hz})$ & $3726.47 \pm 115.61(3593.93-3914.10)$ \\
\hline Peak frequency of 2 nd note $(\mathrm{Hz})$ & $3544.15 \pm 148.96(3323.26-3793.40)$ \\
\hline Lower frequency of 2 nd note $(\mathrm{Hz})$ & $3158.91 \pm 96.27(2984.26-3339.53)$ \\
\hline Upper frequency of 2 nd note $(\mathrm{Hz})$ & $4016.99 \pm 96.14(3889.66-4162.56)$ \\
\hline Peak frequency of 3 rd note $(\mathrm{Hz})$ & $3462.92 \pm 142.64(3294.60-3761.13)$ \\
\hline Lower frequency of 3rd note $(\mathrm{Hz})$ & $3119.70 \pm 99.21(2898.86-3264.46)$ \\
\hline Upper frequency of $3 \mathrm{rd}$ note $(\mathrm{Hz})$ & $3800.87 \pm 144.94(3667.40-4048.70)$ \\
\hline Peak frequency of 4 th note $(\mathrm{Hz})$ & $3582.00 \pm 159.78(3323.26-3836.50)$ \\
\hline Lower frequency of 4 th note $(\mathrm{Hz})$ & $3217.23 \pm 98.90(3007.53-3383.50)$ \\
\hline Upper frequency of 4th note $(\mathrm{Hz})$ & $4095.87 \pm 107.19(3969.93-4284.20)$ \\
\hline Peak frequency of 5 th note $(\mathrm{Hz})$ & $3461.61 \pm 140.79(3301.76-3739.56)$ \\
\hline Lower frequency of 5 th note $(\mathrm{Hz})$ & $3122.54 \pm 102.52(2911.80-3261.90)$ \\
\hline Upper frequency of 5 th note $(\mathrm{Hz})$ & $3809.93 \pm 133.58(3667.36-4048.70)$ \\
\hline Peak frequency of 6 th note $(\mathrm{Hz})$ & $3583.63 \pm 160.45(3323.26-3836.50)$ \\
\hline Lower frequency of 6th note $(\mathrm{Hz})$ & $3219.01 \pm 96.77(3030.86-3404.23)$ \\
\hline Upper frequency of 6th note $(\mathrm{Hz})$ & $4101.78 \pm 109.35(3977.66-4302.33)$ \\
\hline
\end{tabular}

\section{RESULTS}

Advertisement calls of Allobates femoralis from the Altamira region are formed by the repetition of six notes arranged in couplets. We define each sequence of calls as a call bout (Fig. 3a). Within bouts, individual calls (i.e. groups of three couplets) are $0.64 \mathrm{~s}$ long in average. The first note of each couplet is shorter (generally $0.04 \mathrm{~s}$ long, in average) than the following note ( $0.06 \mathrm{~s}$ long, in average) (Fig. 3b). Within couplets, notes are split by a very short $(0.03 \mathrm{~s}$ long $)$ silent interval. Couplets are split by longer $(\sim 0.10-0.12 \mathrm{~s}$ long) silent intervals (Tab. I). Notes are tonal, with ascending frequency. Frequency modulation is narrower in the first note of each couplet (Fig. 3b). The average peak frequency of the advertisement call is around $3.5 \mathrm{kHz}$, call bandwidth is generally between 3.1 and 4.1 $\mathrm{kHz}$ (minimum observed value for lower frequency of call is $2.9 \mathrm{kHz}$, and maximum value for upper frequency of call is $4.3 \mathrm{kHz}$ ) (Tab. I).

From a total of 30 playback experiments conducted at RFAD, only one focal male did not orient towards the loudspeakers, and three others did not approach past the $30 \mathrm{~cm}$ threshold. These four males were tested with stimuli built from six-note calls recorded in Altamira. Latency to orientation did not differ between males tested with stimuli built from four-note calls from RFAD or Belterra, but it was more variable (and generally longer) among males tested with six-note stimuli (Fig. 4a). The different stimuli did not produce the differences in the times of approach of the individuals toward the loudspeakers. (Fig. 4b). The four males that did not reach the loudspeaker when tested with six-note calls stimuli responded readily to subsequent control-tests, approaching and reaching loudspeakers when four-note stimuli built from calls of sympatric males were broadcast. 
Tab. II. Characterization of acoustic stimuli used in the playback experiments conducted at Reserva Florestal Adolpho Ducke (RFAD-AM), in Manaus, State of Amazonas, Brazil, from December 2011 to April 2012. Values are means \pm one standard deviation and values in parentheses denote the full range of values of the acoustic parameters measured from three calls sampled from each of ten independent stimuli $(\mathrm{n}=30$ calls analyzed per treatment).

\begin{tabular}{|c|c|c|c|c|}
\hline Locality & $\begin{array}{l}\text { Number of notes } \\
\text { per call }\end{array}$ & Call duration (s) & $\begin{array}{l}\text { Peak frequency of call } \\
(\mathrm{Hz})\end{array}$ & $\begin{array}{l}\text { Duration of silent interval between } \\
\text { consecutive calls (s) }\end{array}$ \\
\hline \multirow{2}{*}{ RFAD-AM } & \multirow{2}{*}{4} & $0.54 \pm 0.03$ & $2871 \pm 211.3$ & $0.47 \pm 0.09$ \\
\hline & & $(0.46-0.58)$ & $(2548.1-3222.8)$ & $(0.36-0.69)$ \\
\hline \multirow{2}{*}{ Belterra-PA } & \multirow{2}{*}{4} & $0.43 \pm 0.04$ & $3270.7 \pm 162.8$ & $0.4 \pm 0.05$ \\
\hline & & $(0.37-0.52)$ & $(2991.3-3484.3)$ & $(0.33-0.491)$ \\
\hline \multirow{2}{*}{ Altamira-PA } & \multirow{2}{*}{6} & $0.67 \pm 0.03$ & $3571 \pm 173.8$ & $70.96 \pm 222.7$ \\
\hline & & $(0.614-0.726)$ & $(3359.2-3832.9)$ & $(0.436-704.9)$ \\
\hline
\end{tabular}

\section{DISCUSSION}

Our results show that calls emitted by Allobates femoralis males from the Altamira region are generally recognized by territorial conspecific males inhabiting forests in the vicinities of Manaus. However, not all tested males responded aggressively to those differentiated calls, hinting at a complex scenario of conspecific acoustic signal recognition. Previous studies using $A$. femoralis synthetic calls found that extreme variations in their temporal (note duration and inter-note silent intervals) and spectral (frequency) properties influence male-to-male intraspecific recognition and aggressive territorial responses (AMÉZQUITA et al., 2005; GöD et al., 2007), which can be also modulated by intra and interspecific visual stimuli (NARINS et al., 2003; LUNA et al., 2010). However, the species has a wide acoustic recognition space when compared to evolutionarily related species (AMÉZquita et al., 2011). Indeed, previous experiments using natural calls from several allopatric populations failed to detect any differences in the aggressive responses of males when exposed to a varying number of notes in the calls (ERDTMANN et al., 2011).

Most males tested at RFAD recognized stimuli built from calls recorded in Altamira as conspecific, responding aggressively towards their broadcast source. However, based on the highly variable behavioral responses, the ability to recognize such calls is probably not equal among individuals inhabiting the RFAD. Four out of ten tested males did not react to playbacks of calls formed by six notes, while all individuals tested with allopatric and sympatric four-note stimuli responded promptly and rather stereotypically to playbacks.

Ultimately, the effects of advertisement call differentiation on evolutionary processes leading to genetic divergence or speciation should be evaluated by measuring the response of females towards differentiated calls. However, courtship behavior is long and complex in A. femoralis, and involves a large array of acoustic, visual and tactile cues (RoITHMAIR, 1994; MONTANARIN et al., 2011). So far, female $A$. femoralis were irresponsive to playback trials conducted in the field, laboratory, or semi-captive conditions (L. K. Erdtmann and the authors, unpublished data) and the best approximation to test intraspecific recognition in territorial anuran species while overcoming issues relating to female availability and motivation is to make use of male-male recognition experiments, as males frequently exhibit conspicuous and measurable behavioral responses. These can be readily associated with male's perception of intraspecific sound signals (Ryan \& Rand, 2001; Gerhardt \& Huber, 2002).

Detailed characterizations of advertisement call repertoires have led to important advances in anuran taxonomy and conservation in the Neotropics, being especially important in the discovery of new taxa (e.g., Angulo \& ICOChea, 2010; Magalhães et al., 2014; ORRICO et al., 2014), of evolutionary significant units and areas of increased scientific interest, such as hybrid

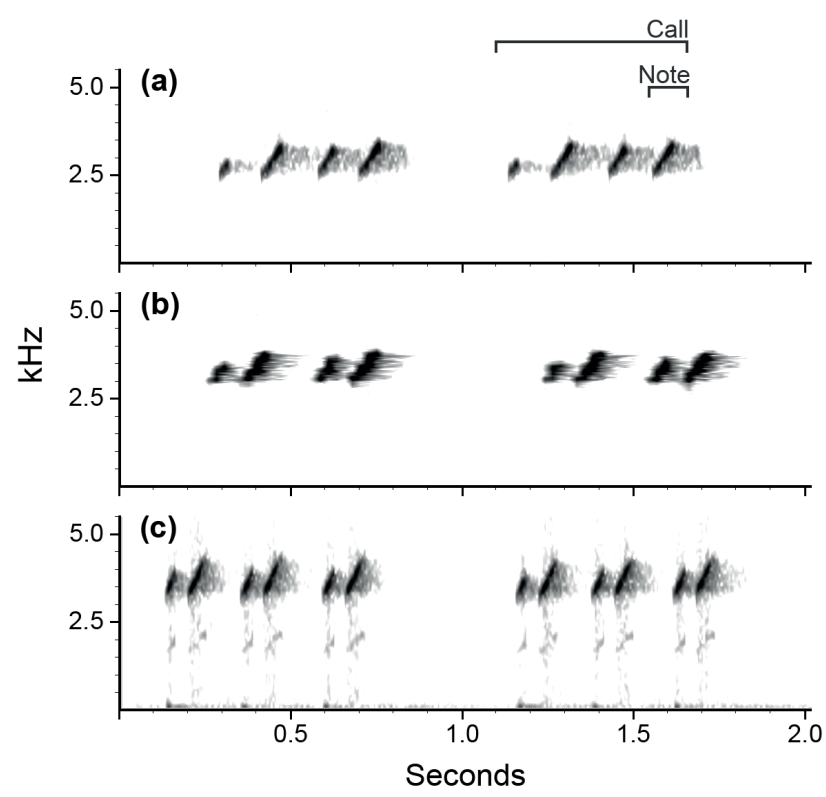

Fig. 2. Sample spectrograms of stimuli used in the playback experiments conducted at Reserva Ducke (RFAD), in Manaus, Brazil, from December 2011 to April 2012. The original advertisement calls of $A$. femoralis males used for the stimuli were recorded in (a) RFAD, Manaus, State of Amazonas, Brazil in June 2008, by L. K. Erdtmann; (b) Belterra, State of Pará, Brazil, in January 2007, by P. I. Simões; (c) Altamira, State of Pará, Brazil, in March 2009, by A.P. Lima. Air temperature at the time of recording was $24.7^{\circ} \mathrm{C}, 24.7^{\circ} \mathrm{C}, 28.6^{\circ} \mathrm{C}$, respectively. Advertisement calls were analyzed in Raven 1.2 using Blackmann window, $80 \%$ overlapping and a fast Fourier transform with frequency resolution of $80 \mathrm{~Hz}$ and 2048 points. 

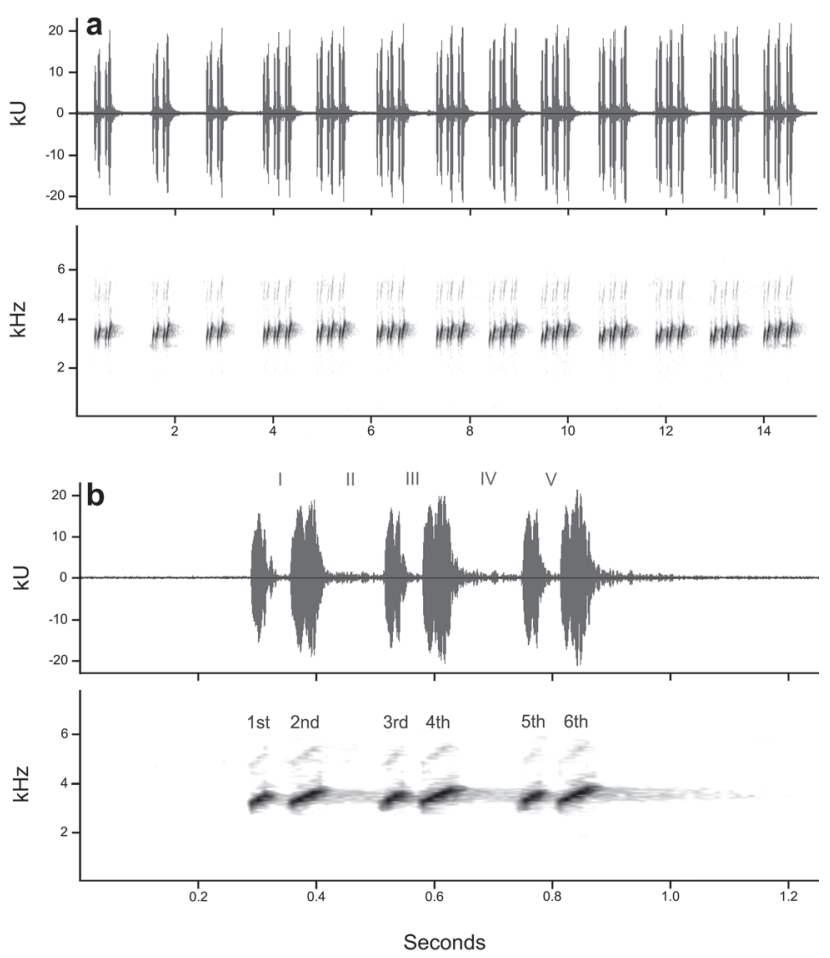

Fig. 3. (a) Waveform (upper graph) and spectrogram (lower graph) of a $14 \mathrm{~s}$ bout of advertisement calls of Allobates femoralis (Boulenger, 1884) recorded near Altamira, State of Pará, Brazil. First three calls are considered warm-up calls, formed by four notes. Remaining calls are formed by six notes. (b) Detailed view of waveform and spectrogram of a single call formed by six notes, originating from the same call bout. Roman numerals correspond to the designation of silent intervals between notes; arabic numerals correspond to the designation of notes (see Table 1 for a description of parameters of notes and silent intervals). Air temperature at the time of recording was $29.0^{\circ} \mathrm{C}$. zones (Simões et al., 2008; Brown \& Twomey, 2009). The characterization of $A$. femoralis advertisement calls recorded near Altamira adds to previous work that sampled the species' repertoire. It might influence future reappraisals of the species' biogeography (AMÉZQUiTA et al., 2009) and sound signal evolution and its correlates (SANTOS et al., 2014), for which comprehensive data on intraspecific variation are desirable. Importantly, the recognition of the new, six-note call arrangement in the field led to concomitant DNA barcoding that associated this call morphotype to unique and distinct mitochondrial DNA haplotypes (SimõES et al., 2014).The description presented in this study can therefore be used in the forthcoming years in monitoring programs to confirm whether the distribution of this lineage is restricted to forest remnants in or near sites impacted by the Belo Monte dam, on the Xingu River (Simões et al., 2014).

Here, we report a case of conspicuous behavioral differentiation among allopatric populations of a widespread Amazonian anuran. While further experiments may be needed to confirm statistically whether the reported acoustic differentiation influences current speciation processes, a readily diagnosable evolutionary lineage might be at risk of obliteration by ongoing developmental projects in the mid and lower courses of the Xingu River. Additional studies should include active surveys in order to clarify this lineage's real geographic range, as well as experimental studies to evaluate whether individuals of Altamira recognize alopatric calls or whether reported call differences are likely to influence female partner choice and male reproductive success in that region.
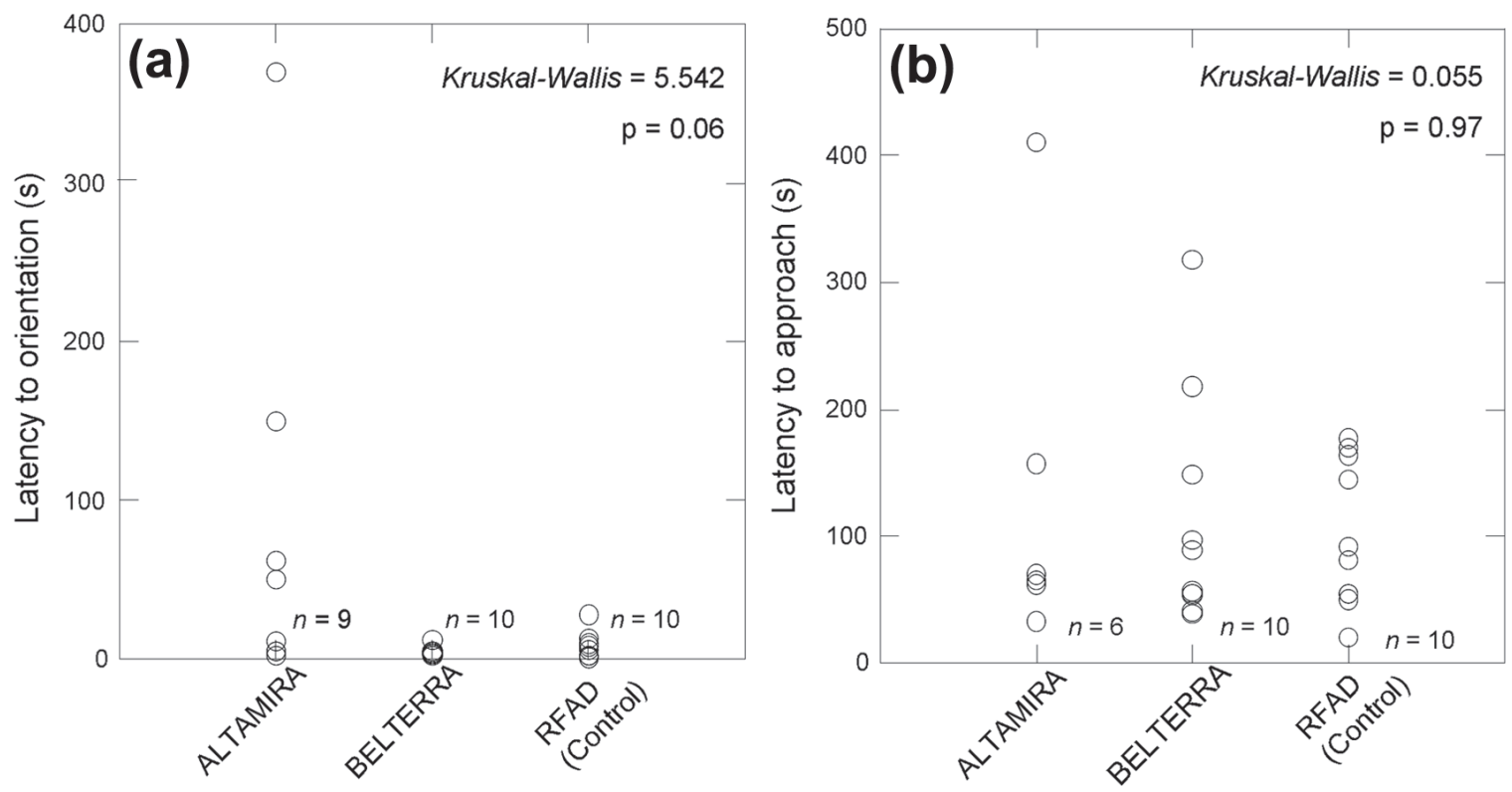

Origin of acoustic stimuli

Fig. 4. (a) Differences in latency to first orientation towards loudspeakers of male Allobates femoralis (Boulenger, 1884) tested at RFAD with playbacks of acoustic stimuli built from recordings of natural calls. (b) Differences in latency to focal males approach within $30 \mathrm{~cm}$ of loudspeakers in the same experiments. Values in top-right corner of (b) and (c) correspond to Kruskall-Wallis Test statistics and p-values, assuming Chi-square distribution with two degrees of freedom. 
Acknowledgements. We thank Mario Jorge, João Bosco, Gabriel Muca, Andre Lima, Danillo Alves, and Vanessa Gama for helping us in fieldwork. We thank Luciana K. Erdtmann for providing original recordings from RFAD. Call recordings are managed by Centro para Estudos Integrados da Amazônia (INCT-CENBAM), as part of Centro para Estudos Integrados da Amazônia "CENBAproject "Sapoteca" (http://ppbio.inpa.gov. $\mathrm{br} / \mathrm{sapoteca}$ /paginainicial).This work was supported by Conselho Nacional de Desenvolvimento Científico e Tecnológico $(\mathrm{CNPq})$ under training grant to EPS (PIBIC/CNPq-INPA/2011-2012); PIS received a research fellowship from CNPq (PCI/CNPq-INPA, Proc. 300975/2011-2) and currently receives a post-doctoral fellowship from PNPD-CAPES through Programa de PósGraduação em Zoologia of PUCRS.

\section{REFERENCES}

AmÉzquita, A.; Castellanos, L. \& HöDl, W. 2005. Auditory matching of male Epipedobates femoralis (Anura: Dendrobatidae) under field conditions: the role of spectral and temporal call features. Animal Behavior 70:1377-1386.

AmÉzquita, A.; HödL, W.; Lima, A. P.; Castellanos, L.; Erdtmann, L. \& ARaúJo, M. C. 2006. Masking interference and the evolution of the acoustic communication system in the Amazonian dendrobatid frog Allobates femoralis. Evolution 60(9):1874-1887.

Amézquita, A.; lima, A. P.; Jehle, R.; Castellanos, L.; Ramos, O.; CRAWFORD, A. J.; GASSER, H. \& HÖDL, W. 2009. Calls, colours, shapes, and genes: A multi-trait approach to the study of geographic variation in the Amazonian frog Allobates femoralis. Biological Journal Linnean Society 98:826-838.

Amézquita, A.; Flechas, S. V.; Lima, A. P.; Gasser, H. \& Hödl, W. 2011. Acoustic interference and recognition space within a complex assemblage of dendrobatid frogs. PNAS 108(41):17058-17063.

Angulo, A. \& ICOCHEA, J. 2010. Cryptic species complexes, widespread species and conservation: lessons from Amazonian frogs of the Leptodactylus marmoratus group (Anura: Leptodactylidae). Systematics and Biodiversity 8:357-370.

Bee, M. A.; Kozich, C. E.; Blackwell, K. J. \& Gerhardt, H. C. 2001. Individual variation in advertisement calls of territorial male green frogs, Rana clamitans: Implications for individual discrimination. Ethology 107:65-84.

Boul, K. E.; FunK, W. C.; Darst, C. R.; Cannatella, D. C. \& Ryan, M. J. 2007. Sexual selection drives speciation in an Amazonian frog. Proceedings of the Royal Society B: Biological Sciences 274:399-406.

Brown, J. L. \& TwomeY, E. 2009. Complicated histories: three new species of poison frogs of the genus Ameerega (Anura: Dendrobatidae) from north-central Peru. Zootaxa 2049:1-38.

Charif, R. A.; Clark, C. W. \& Fristrup, K. M. 2004. Raven 1.3 User's Manual. Ithaca, Cornell Laboratory of Ornithology. 191p.

Donnelly, M. A. 1989a. Demographic effects of reproductive resource supplementation in a territorial frog, Dendrobates pumilio. Ecological Monographs 59(3):207-221.

DonNelly, M. A. 1989b. Effects of reproductive resource supplementation on space-use patterns in Dendrobates pumilio. Oecologia 81(2):212-218.

Erdtmann, L. K.; Simões, P. I.; Mello, A. C. \& Lima, A. P. 2011. Do natural differences in acoustic signals really interfere in conspecific recognition in the pan-Amazonian frog Allobates femoralis? Behaviour 148:485-500.

Fearnside, P. M. 2006. Dams in the Amazon : Belo Monte and Brazil's hydroelectric development of the Xingu River basin. Environmental Management 38:16-27.

GerhaRdT, H. C. 1992. Multiple messages in acoustic signals. Seminars in Neuroscience 4:391-400.

Gerhardt, H. C. \& Huber, F. 2002. Acoustic communication in insects and anurans: Common problems and diverse solutions. Chicago, University of Chicago Press. 542p.

GöD, M.; FRANZ, A. \& HöDL, W. 2007. The influence of internote-interval variation of the advertisement call on the phonotacticbehavior in male Allobates femoralis (Dendrobatidae). Amphibia-Reptilia 28:227-234.

Grant, T.; Frost, D. R.; Caldwell, J. P.; Gagliardo, R.; Haddad, C. F. B.; KoK, P. J. R.; Means, B. D.; NoOnan, B. P.; Schargel, W. \&
WheELER, W. C. 2006. Phylogenetic systematics of dart-poison frogs and their relatives (Anura: Athesphatanura: Dendrobatidae). Bulletin of the American Museum of Natural History 299:1-262.

Guerra, M. A. \& Ron, S. 2008.Mate choice and courtship signal differentiation promotes speciation in an Amazonian frog. Behavioral Ecology 19(6):1128-1135.

HöDL, W. 1987. Dendrobates femoralis (Dendrobatidae): a handy fellow for frog bioacoustics. Proceedings of the 4th Ordinary General Meeting of the Societas Europea Herpetologica. Nijmegen 1987:201-204.

Lima, A. P.; Magnusson, W. E.; Menin, M.; ErdtMann, L. K.; Rodrigues, D. J.; Keller, C. \& HöDL, W. 2006. Guide to the frogs to Reserva Adolpho Ducke, Central Amazonia. Manaus, Attema. 168p.

LunA, A.G.; AMÉzquitA, A. \& HöDL, W. 2010. Colour, size and movement as visual sub-components in multimodal communication by the frog Allobates femoralis. Animal Behavior 79:739-745.

Magalhães, F. M.; Loebmann, D.; Kokubum, M. N. C.; Haddad, C. F. B. \& GARDA, A. A. 2014. A new species of Pseudopaludicola (Anura: Leptodactylidae: Leiuperinae) from Northeastern Brazil. Herpetologica 70(1):77-88

Montanarin, A.; KaEFer, I. L. \& Lima, A. P. 2011. Courtship and mating behaviour of the brilliant-thighed frog Allobates femoralis from Central Amazonia: implications for the study of a species complex. Ethology, Ecology and Evolution 23(2):141-150.

NARINS, P. M.; HöDL, W. \& GRABUL, D. S. 2003. Bimodal signal requisite for agonistic behavior in a dart-poison frog, Epipedobates femoralis. Proceedings of the National Academy of Sciences USA 100:577-580. Orrico, V. G. D.; Peloso, P. L. V.; Sturaro, M. J.; Silva-Filho, H. F.; Neckel-Oliveira, S.; Gordo, M.; Faivovich, J. \& Haddad, C. F. B. 2014. A new "Bat-Voiced" species of Dendropsophus Fitzinger, 1843 (Anura, Hylidae) from the Amazon Basin, Brazil. Zootaxa 3881:341-361.

Poelman, E. H. \& Dicke, M. 2008. Space use of Amazonian poison frogs: testing the reproductive resource defense hypothesis. Journal of Herpetology 42(2):270-278.

PRöHL, H. 2005. Territorial behavior in dendrobatid frogs. Journal of Herpetology 39:354-365.

RodRÍGUEZ, A.; DE LA NUEZ, D. \& ALONSO, R. 2010. Intraspecific variation in the advertisement call of the Cloud-Forest Frog Eleutherodactylus glamyrus (Anura: Eleutherodactylidae). Journal of Herpetology 44(3):457-466

RoIthmaIR, M. E. 1994. Field studies on reproductive behaviour in two dartpoison frog species (Epipedobates femoralis, Epipedobates trivittatus) in Amazonian Peru. Herpetology Journal 4:77-85.

RYAN, M. J. \& RAND, A. S. 2001. Feature weighting in signal re-cognition and discrimination by Tungara frogs. In: RYAN, M. J. ed. Anuran Communication. Washington, Smithsonian Institution Press, p. 86-101.

RYAN, M. J. \& RAND, A. S. 2003. Sexual selection in female perceptual space: how female túngara frogs perceive and respond to complex population variation in acoustic mating signals. Evolution 57:2608-2618.

Santos, J. C.; Coloma, L. A.; Summers, K.; Caldwell, J. P.; Ree, R. \& CANNATELla, D. C. 2009. Amazonian amphibian diversity is primarily derived from Late Miocene Andean lineages. PLOS Biology 7(3):1-14.

Santos, J. C.; Baquero, M.; Barrio-Amorós, C.; Coloma, L. A.; Erdtmann, L. K.; Lima, A. P. \& Cannatella, D. C. 2014. Aposematism increases acoustic diversification and speciation in poison frogs. Proceedings of the Royal Society B: Biological Sciences 281:20141761.

Seví Filho, A. O. ed. 2005. Tenotã-mõ: alertas sobre as consequências dos projetos hidrelétricos no rio Xingu, Pará, Brasil. São Paulo, International Rivers Network. 344p.

Simões, P. I. \& Lima, A. P. 2011. The complex advertisement calls of Allobates myersi (Pyburn, 1981) (Anura: Aromobatidae) from São Gabriel da Cachoeira, Brazil. Zootaxa 2988:66-68.

Simões, P. I.; Lima, A. P.; Magnusson, W. E.; HödL, W. \& AmÉzQuita, A. 2008. Acoustic and morphological differentiation in the frog Allobates femoralis: relationships with the upper Madeira River and other potential geological barriers. Biotropica 40:607-614.

Simões, P. I.; Lima, A. P. \& Farias, I. P. 2010. The description of a cryptic species related to the pan-Amazonian frog Allobates femoralis (Boulenger 1883) (Anura: Aromobatidae). Zootaxa 2406:1-28. 
Simões, P. I.; Stow, A.; HöDl, W.; AmÉzouita, A.; Farias, I. P. \& Lima, A. P. 2014. The value of including intraspecific measures of biodiversity in environmental impact surveys is highlighted by the Amazonian brilliant-thighed frog (Allobates femoralis). Tropical Conservation Science 7(4):811-828.

URSPRUNG, E.; RINGLER, M. \& HöDL, W. 2009. Phonotactic approach pattern in the neotropical frog Allobates femoralis: A spatial and temporal analysis. Behaviour 146:153-170.

WeLLS, K. D. 2007. The ecology and behavior of amphibians. Chicago, The University of Chicago Press. 1400p.

WILKINSON, L. 1990. SYSTAT: the system for statistics. Evanston, SYSTAT Inc. 